\title{
Knowledge, attitude and practice of contraception: a study from rural tertiary health care centre
}

\author{
Beenu Kushwah*, Sonal Agrawal
}

\begin{abstract}
Department of Obstetrics and Gynaecology, Shyam Shah Medical College and Associated Sanjay Gandhi and Gandhi
\end{abstract} Memorial Hospital, Rewa-486001, Madhya Pradesh, India

Received: 05 January 2015

Accepted: 14 February 2015

\section{*Correspondence:}

Dr. Beenu Kushwah,

E-mail: drbeenukushwah@gmail.com

Copyright: (c) the author(s), publisher and licensee Medip Academy. This is an open-access article distributed under the terms of the Creative Commons Attribution Non-Commercial License, which permits unrestricted non-commercial use, distribution, and reproduction in any medium, provided the original work is properly cited.

\begin{abstract}
Background: Realizing the ill effects of increasing population, India was the first country to have started a state sponsored Family Planning Programme, long back in 1952; India is the second most populous country of the world only after China. To attain the required targets India needs nationwide surveys to assess the practices of contraception especially in poor performing states in order to utilize the available resources according to local needs.

Methods: Hospital based, cross-sectional survey conducted amongst the women of post natal ward of a referral hospital mainly catering rural population. Knowledge, Attitude and Practice survey of family planning was conducted.

Results: A total of 4221 subjects were interviewed.58\% of these women were aware of contraceptive methods, mostly Permanent followed by IUCD, Condom, least of oral pills.

Conclusions: Spacing methods are less known amongst rural women while the use is even lower which calls for the further strengthening of existing awareness programmes.
\end{abstract}

Keywords: Contraception, Total fertility rate, Family planning

\section{INTRODUCTION}

On First March 2011, Indian's population stood at 1.21 billion which is projected to be 1.4 billion in $2026 .{ }^{1}$ India which accounts for world's $17.5 \%$ population is the second most populous country in the world next only to China (19.4\%). Of the 1.21 billion Indians, $68.84 \%$ live in rural area while $31.6 \%$ live in urban areas, as per the census 2011. 'Therefore more than half of the total population reside in rural areas in this country.

Despite the fact that India was the first country to start state sponsored Family Planning Programme in 1952, decline in the rate of Total Fertility Rate (TFR) has not been to the extent as was aimed, especially in rural areas. For historical reasons some states in India depicted a tendency of higher growth of population. In order to facilitate the creation of area specific programmes, Government of India in 2001 constituted a group of eight states which were lagging behind in improving their fertility indicators. This group is called as Empowered Action Group (EAG).

Present study was conducted in the state of Madhya Pradesh (MP), one of the members of EAG. Total Fertility Rate (TFR) of MP in 2009 was 3.3, against the national average of 2.6 with even bigger difference between rural and urban areas, rural TFR being 3.6 and urban TFR being 2.3 against the national average of 2.9 and 2 respectively. ${ }^{1}$ 
One of the main objectives of the family planning programme is to spread the knowledge of contraceptive methods and develop, among the people, an attitude favourable for adoption of contraceptive method. The progress achieved in this sphere is normally assessed from the results of Knowledge, Attitude and Practice survey. $^{2}$

Present study was conducted amongst the women of post natal ward of one of the tertiary health care centres of MP. Department of Obstetrics and Gynaecology of Gandhi Memorial Hospital had total 4927 deliveries (vaginal and caesarean) during last 6 months period, 90\% of these women were from rural areas as there is no other equipped government run health care centre is available across a wide area.

\section{METHODS}

This was a Hospital based, cross sectional, observational, descriptive study during a period of 6 months from June to November 2011. After taking informed consents and briefing about the aim of study, a total of 4221 women of post natal ward of our department consented to be interviewed. A 20 point, semi-structured questionnaire was read out to the subjects. Data were collected regarding socio-demographic features, knowledge, attitude and practices of various family planning methods.

\section{RESULTS}

Women of age group 18-35 years, were included in the study, $78 \%$ belonged to $18-22$ years age group. $62 \%$ women were illiterate, $24 \%$ were literate but without any formal schooling, $11 \%$ were literate till primary and rest had studied above primary. Only $3 \%$ were employed with regular source of income, $16 \%$ were running some home business, $12 \%$ were working as helper's at others' houses both with irregular income and $20 \%$ were farmers and were helping their husbands (Table 1).

On assessing the knowledge, it was found that $58 \%$ of the women were aware of at least one of the available family planning methods, maximum knowledge was for permanent method (Tubectomy-56\%, Vasectomy-6\%), followed by IUCD (30\%), Condoms (28\%), and Oral pills $(11 \%)$ (Figure 1). Although majority $(71 \%)$ of all women who had knowledge of any family planning methods showed positive attitude towards use but only $6 \%$ of these had actually used any method ever, of which majority (53\%) had used IUCD, 33\% condoms and only $14 \%$ had used oral pills resulting in a very high knowledge-practice gap i.e. 96\%. None of the participants were aware of emergency contraceptive method (i-pill) (Figure 2, 3).
Table 1: Base line characteristics of study population.

\begin{tabular}{|c|c|c|c|}
\hline SN. & Characteristics & $\begin{array}{l}\text { Number } \\
\text { of females } \\
(\mathrm{N}=\mathbf{4 2 2 1})\end{array}$ & $\begin{array}{l}\text { Percentage } \\
(\%)\end{array}$ \\
\hline 1. & \multicolumn{3}{|c|}{ Present age (in year) } \\
\hline & $<18$ & 42 & 1.0 \\
\hline & $18-22$ & 3292 & 78.0 \\
\hline & $23-27$ & 760 & 18.0 \\
\hline & $>27$ & 127 & 3.0 \\
\hline \multirow[t]{5}{*}{2.} & \multicolumn{3}{|c|}{ Level of education } \\
\hline & Illiterate & 2617 & 62.0 \\
\hline & $\begin{array}{l}\text { Literate (no } \\
\text { formal } \\
\text { schooling) }\end{array}$ & 1013 & 24.0 \\
\hline & $\begin{array}{l}\text { Literate (till } \\
\text { Primary) }\end{array}$ & 464 & 11.0 \\
\hline & $\begin{array}{l}\text { Literate } \\
\text { (>Primary) }\end{array}$ & 127 & 3.0 \\
\hline \multirow[t]{6}{*}{3.} & \multicolumn{3}{|l|}{ Occupation } \\
\hline & $\begin{array}{l}\text { Employed with } \\
\text { regular income }\end{array}$ & 127 & 3.0 \\
\hline & $\begin{array}{l}\text { Home business } \\
\text { (irregular } \\
\text { income) }\end{array}$ & 675 & 16.0 \\
\hline & $\begin{array}{l}\text { Helper at other } \\
\text { houses } \\
\text { (irregular } \\
\text { income) }\end{array}$ & 507 & 12.0 \\
\hline & $\begin{array}{l}\text { Farmers } \\
\text { (irregular } \\
\text { income) }\end{array}$ & 844 & 20.0 \\
\hline & $\begin{array}{l}\text { Housewife (no } \\
\text { income) }\end{array}$ & 2068 & 49.0 \\
\hline \multirow[t]{5}{*}{4.} & \multicolumn{3}{|l|}{ Parity } \\
\hline & One & 1646 & 39.0 \\
\hline & Two & 971 & 23.0 \\
\hline & Three & 1140 & 27.0 \\
\hline & > Three & 464 & 11.0 \\
\hline
\end{tabular}

There was no reliable source of information for majority of participants $(72 \%)$, while health professionals contributed to only $12 \%$ and media to $16 \%$. Only $7 \%$ were satisfied with their current method of use (Figure 4).

Main reason for not practicing one of family planning methods were inefficient accessibility to right information and follow up facility if needed $(69 \%)$, rest were not using any method because of non-cooperation by their husbands and lesser role in decision making.

While majority of participants $(67 \%)$ were willing to use contraceptive method in future, $9 \%$ refused to use any method while $24 \%$ were not able to decide. Amongst those who had positive attitude, majority (64\%) wanted 
to use condom followed by IUCD (28\%) and only $8 \%$ liked pills.

In our study maximum awareness was for permanent method of family planning and nil for emergency contraception while knowledge for temporary methods in present study was relatively low, which is comparable with another study from India3, while it was almost same for all methods in developed regions of world. ${ }^{4,5,6}$



Figure 1: Knowledge regarding each FP method.

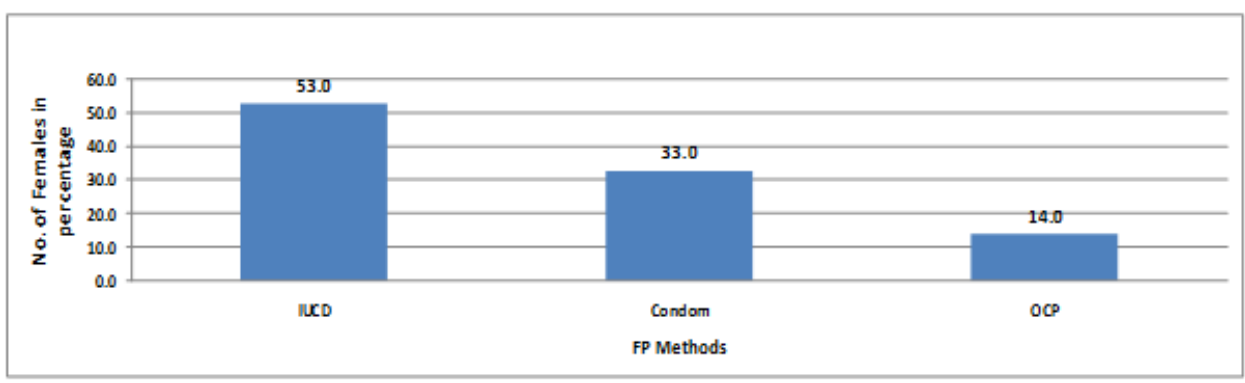

Figure 2: Practice of each FP method.

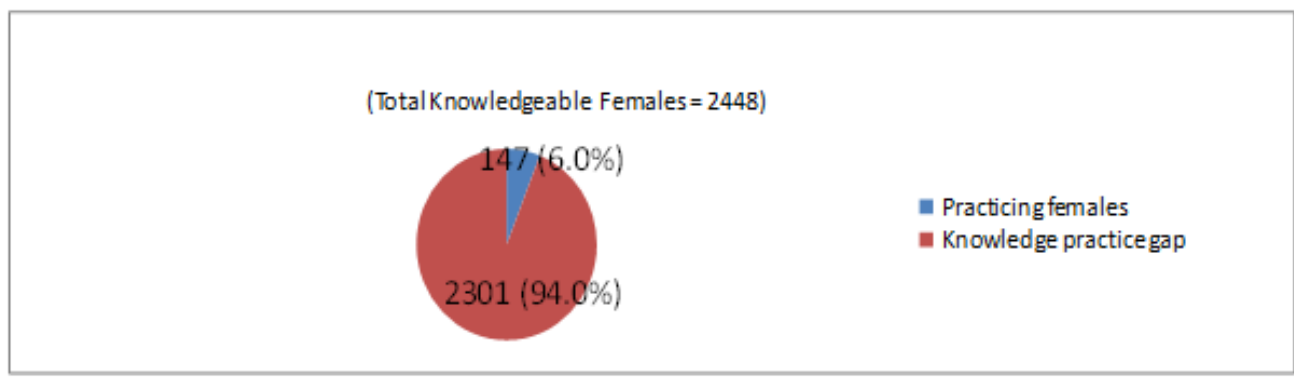

Figure 3: Knowledge practice gap.

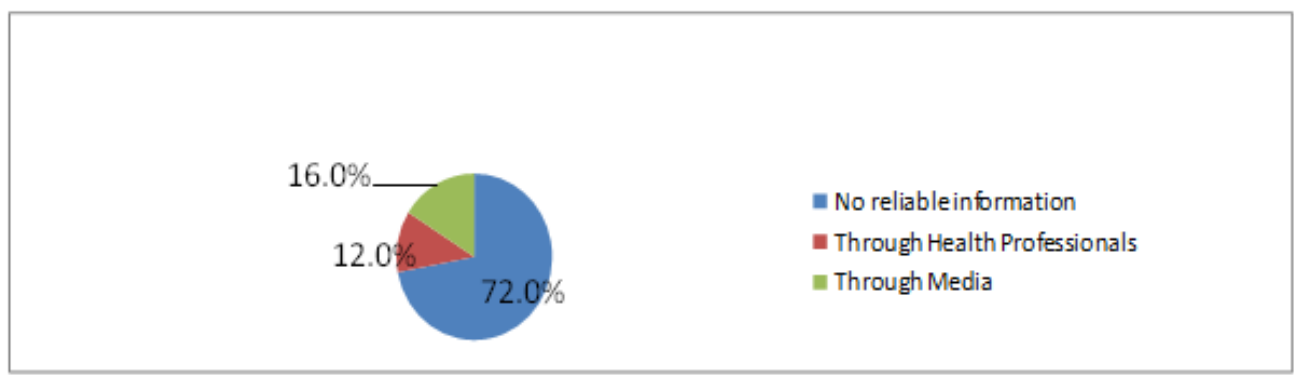

Figure 4: Contribution by different source of information.

\section{DISCUSSION}

In present study oral pills were used by only $4 \%$ women in contrast to the women of the United State ${ }^{7}$ where oral pills are the most popular reversible method of contraception. Other study from $\mathrm{ICMR}^{8}$ also showed low use of oral pills by Indian females, which is comparable to other studies. ${ }^{9,10,11}$ 
The huge knowledge and practice gap of our study has also been observed by others, ${ }^{12,13,14}$ factors which could be identified for this were; wrong information regarding side effects, scarcity of health care facility to consult if required and lesser role in decision making, all of these are directly related with low literacy levels and inadequate inclusion of the educational sessions related with family planning methods by the health professionals. Findings of study from India observed similar gap because of factors directly related with socio economic development. $^{15}$

A study from Reddy et al. ${ }^{16}$ showed relatively low contribution of health care personnel in providing family planning knowledge, which was observed in our study as well. The role of health care personnel in providing contraceptive knowledge should be emphasized as it's a two way communication process.

Sixty one percentage $(61 \%)$ women of our study were Para three and above and $46 \%$ had underwent unconventional methods for termination of pregnancy at least once before present pregnancy, while $26 \%$ had actually wished for termination of present pregnancy but had to continue because of non-availability of the facilities nearby. These findings from our study are an indirect reflection for the need of termination of pregnancy because of poor knowledge and even lesser practice of contraception. According to one study on an average 5 million legal and illegal abortions per annum could be abortion rate of India for current decade. ${ }^{9}$ The Indian Survey of Death reports that nearly $18 \%$ of maternal deaths result from abortion. ${ }^{8}$ Majority of these abortions were illegal and indirectly reflect the significant burden of unmet need of family planning methods available to the women from rural and remote areas.

\section{CONCLUSIONS}

In recent years, the need for studies for assessing prevailing contraceptive practices is very important across various regions of this country to know about regional needs. Results of present study clearly reflect an urgent need for facilitating the access to more information, education and communication with the reproductive couples according to individual needs. This study indicates a pressing need for effective intervention strategies, both at the community and clinic level, backed with efficient counselling, motivation and provision of services in Rural and Remote areas.

Funding: No funding sources Conflict of interest: None declared

Ethical approval: The study was approved by the Institutional Ethics Committee

\section{REFERENCES}

1. Family Welfare Statistics in India 2011: Statistics Division, Ministry of Health and Family Welfare, Government of India.

2. Mao J. Knowledge, Attitude and Practices of Family Planning: A study of Tezu Village, Manipur (India). The Internet Journal of Biological Anthropology, 2006;1(1).

3. Reena S, Kumar SD, Radha J, Kumkum S, Neela S,Sushmita S. Contraceptive knowledge attitude and practice (KAP) survey. J Obstet Gynecol India. 2005;55(6):546-50.

4. Young LK, Farquhar CM, McCowan LM, Roberts HE,Taylor J. The contraceptive practices of women seeking termination of pregnancy in an Auckland clinic. N Z Med J. 1994;107(978):189-92.

5. Aneblom G, Larsson M, Odlind V,Tyden $T$. Knowledge, use and attitudes towards emergency contraceptive pills among Swedish women presenting for induced abortion. BJOG. 2002;109(2):155-60.

6. Bromham DR, Cartmill RS. Knowledge and use of secondary contraception among patients requesting termination of pregnancy. Bmj. 1993;306(6877):5567.

7. Johansson ED. Future developments in hormonal contraception. Am J Obstet Gynecol. 2004;190(4 Suppl):S69-71.

8. Baveja R, Buckshee K, Das K, Das SK, Hazra MN, Gopalan S, et al. Evaluating contraceptive choice through the method-mix approach. An Indian Council of Medical Research (ICMR) task force study. Contraception. 2000;61(2):113-9.

9. Takkar N, Goel P, Saha PK,Dua D. Contraceptive practices and awareness of emergency contraception in educated working women. Indian $\mathrm{J}$ Med Sci. 2005;59(4):143-9.

10. Mittal S, Bahadur A,Sharma JB. Survey of knowledge, attitude and practice of contraception and medical abortion in women attending family planning clinic. J Turkish-German Gynecol Assoc. 2008;9(1):29-34.

11. Song D, Zhang W, Chames MC, Guo J. Myomectomy during cesarean delivery. Int $\mathbf{J}$ Gynaecol Obstet. 2013;121(3):208-13.

12. Mahawar P, Anand S, Raghunath D,Dixit S. Contraceptive Knowledge, Attitude and Practices in mothers of Infants: A Cross Sectional study. National Journal of Commuity MedicineQ. 2011;2(1):105-7.

13. Sharma V,Sharma A. Training of opinion leaders in family planning in India: does it serve any purpose? Rev Epidemiol Sante Publique. 1996;44(2):173-80.

14. Sharma V, Sharma A. Family planning practices among tribals of South Rajasthan, India. J Res Educ Indian Med. 1991;10(4):5-9.

15. Gautam AC,Seth PK. Appraisal of the knowledge, attitude and practices (KAP) of family control devices among rural rajputs and Scheduled caste of Hatwar area of Bilaspur district, Himachal Pradesh. Anthropologist. 2001;4(4):289-92. 
16. Rajesh RS, Premarajan KC, A NK,Mishra AK. Rapid appraisal of knowledge, attitude and practices related to family planning methods among men within 5 years of married life. Indian J. Prev. Soc. Med. 2003;34(1,2):62-7.
DOI: $10.5455 / 2320-1770 . i j r \operatorname{cog} 20150408$

Cite this article as: Kushwah B, Agrawal S.

Knowledge, attitude and practice of contraception: a study from rural tertiary health care centre. Int $\mathbf{J}$ Reprod Contracept Obstet Gynecol 2015;4:329-33. 